\title{
Nesting features and breeding chronology of the crested coot (Fulica cristata) in two North African high altitude wetlands
}

\author{
Karima Es Salai ${ }^{\text {(iD) }}$ | Ismail Mansouri ${ }^{2 *}$ (D) | Wafae Squalli ${ }^{\text {(D) }}$ | Abderahim El Hassani ${ }^{\mathrm{b}}$ | \\ Mohamed Dakki | Nasser Eddine Zine
}

ababoratory of environment, ecology and health, Faculty of Science, Moulay Ismail University, BP 4010, Beni M'hamed, Meknès, Morocco.

baboratory of Functional Ecology and Environment, Faculty of Sciences and Technology, Sidi Mohamed Ben Abdellah University, po.box 2202 -Imouzzer street, Fez, Morocco.

Wetlands Unit, Scientific Institute, Mohammed V University in Rabat, BP 703, Agdal, 10090, Rabat, Morocco.

*Corresponding author: mankhori@gmail.com

\begin{abstract}
The current study aimed to investigate the nesting behavior and breeding chronology of the crested coot (Fulica cristata) in Morocco's high altitude wetlands. We monitored nesting activities and breeding phenology in two wetlands, Zerrouka and Hachlaf lakes, to achieve our goals. Besides, nesting materials and nest dimensions were analyzed to characterize the crested coot nests. As a result, 52 nests were found in two sites, 18 in Zerouka and 34 in Hachlaf. Nests were built by available twigs on each site, and nest dimensions varied between analyzed wetlands. Nests were larger in Zerrouka compared to Hachlaf Lake. To protect their nests, coots select open waters and submerged vegetation as nesting sites. On the other hand, breeding chronology, including nesting, laying, and hatching dates, was earlier in Zerrouka Lake than Hachlaf. The nesting activities started at Zerrouka during January and February, while at Hachlaf, breeding attempts started during April.
\end{abstract}

Keywords breeding chronology, crested coot, lakes, nests, Morocco

\section{Introduction}

Nest building in bird species is a widespread, commonly observed behavior, and yet we understand relatively little about how species build what appear to be species-specific nests (Collias and Collias 1984; Hansell 2000; Moller 2006; Raby and Clayton 2009). Understanding how nest construction is achieved and the different aspects surrounding it are key to clarifying the nesting ecology of avian species. However, nest construction involves selecting nesting sites, appropriate material, and manipulating bird's or birds' material into a species-typical building (Collias and Collias 1984). For the selection of nesting material, birds may have unlearned rules of what to choose. In many cases, birds select suitable materials to support nest structure to hold eggs and chicks during incubation. Similarly, fresh green plant material to dry nest material is widespread among birds (Newton 1979; Wimberger 1984). These green materials are often replenished daily during the incubation and nestling phases (Newton 1979; Wimberger 1984) to maintain nest structure and repellent against pathogens.

The importance of nesting materials is similar to the importance of breeding chronology in bird species (Hilton et al 2004) because breeding phenology, including nesting activities, allows species predator avoidance and access to abundant resources (Martin 1987; Stone et al 2017). Bird species select the breeding time during suitable periods to ensure better breeding success (Mansouri et al 2020). On the other hand, many migrant birds select their breeding chronology during the appropriate environmental condition to protect nestlings against harsh climate (Møller et al 2010). But, in sedentary species, little attention was paid to breeding chronology, despite its implication in breeding attempts. Moreover, with climate change, many avian species have shifted their breeding and migration dates as an adjustment to avoid the negative consequences of these new environmental conditions (Balbontín et al 2009). The less adapted species have undergone negative impacts, including nesting failures, loss of nestling, and breeding success reduction. Therefore, the analysis of breeding chronology in avian species is crucial to understanding their breeding ecology and the impact of the climatic conditions on it.

The crested coot (Fulica cristata) is one of the bird species at risk of extinction in many European ranges. Therefore, it is classified as being "in danger of extinction" and is protected by the Bird Directive of the European Union and the Berne Convention. Threatening factors include the loss and degradation of breeding and foraging wetland habitats, shooting, and fishing activities, mainly unsustainable actions (Amat Juan and Green 2010; Amat Juan and Raya 2004). The crested coot's Moroccan population is widely analyzed in terms of habitat use and wintering features (Amezian et al 2007; El Agbani et al 2011; El Hassouni et al 2009). Nevertheless, no study has focused on nesting ecology 
and breeding chronology of this species, even though such studies can yield valuable breeding population size, breeding success (Mansouri et al 2020), and national conservation status. Moreover, conducting such studies in natural habitats is particularly relevant as a first step to understand the bioecology and conservation status of this migrant and breeding species (Madrono et al 2004). In this context, we aim to study the nesting behavior and breeding chronology of the crested coot in the Middle Atlas region that houses most national wetlands, including Ramsar sites.

\section{Materials and Methods}

\subsection{Study sites}

The present study was carried out in Ifran province, Morocco (Figure 1). The selected zone is located in the Middle Atlas, with an altitude ranging from 1600 to $1700 \mathrm{~m}$ above sea level and dominated by farmlands and forests that offer the necessary nesting supports (trees) and food resources for avian species during breeding seasons. Moreover, the climate is humid, with an annual average temperature of $11.3{ }^{\circ} \mathrm{C}$ and precipitations around $843 \mathrm{~mm}$ annually. Besides, this strategic zone is characterized by the diversity of wetlands, including dams, lakes, and rivers that could offer suitable habitats for waterbirds counting the crested coot.

Two wetlands were selected and monitored (Figure 1). The first site is the Zerrouka artificial reservoir, located at the permanent spring of the Zerrouka river. This reservoir is a sport fishing lake of 3.5 hectares and a maximum depth of $3 \mathrm{~m}$. The aquatic vegetation of Zerrouka is characterized by
Potamogeton pectinatus, Ranunculus aquatilis, Myriophyllum spicatum, Polygonum amphibium, and Elodea spp. The lake borders are occupied by emergent vegetation, mainly composed of Typha latifolia, Scirpus lacustris, Juncus bufonius, Carex spp., lined on its outer side by a row of poplar Populus alba. The second habitat is Hachlaf Lake, a shallow marshland with 1-2 m depth, located at an altitude of 1660 $\mathrm{m}$, Northeast of Ifrane city; it extends over approximately 14 ha (Figure 1). Potamogeton pectinatus, Ranunculus aquatilis, Myriophyllum spicatum, Ceratophyllum spp. and Polygonum amphibium compose the aquatic vegetation (Hammada et al 2002).

\subsection{Methods}

Fieldwork was carried out weekly, and nests were explored inside lakes' vegetation. Recorded nests were mapped and labeled with a different code, besides the nest's height $(\mathrm{cm})$ above water, and its diameters (external and internal) were measured. Nesting locality was estimated visually to investigate nesting behavior (nesting sites in open waters, borders, or in islets) concerning the water body. In parallel, at the end of breeding periods (2018 and 2019), nests were taken and analyzed in the laboratory to identify their composition concerning nesting materials.

After installing coots in the selected sites between December and January, the breeding surveys were elapsed, the nesting time, which first and the last nest recorded during each breeding season. Besides, laying dates (first egg after nest constructions and last egg after least nest) and hatching (first hatched egg and last hatched eggs for each season) were monitored weekly for each site.

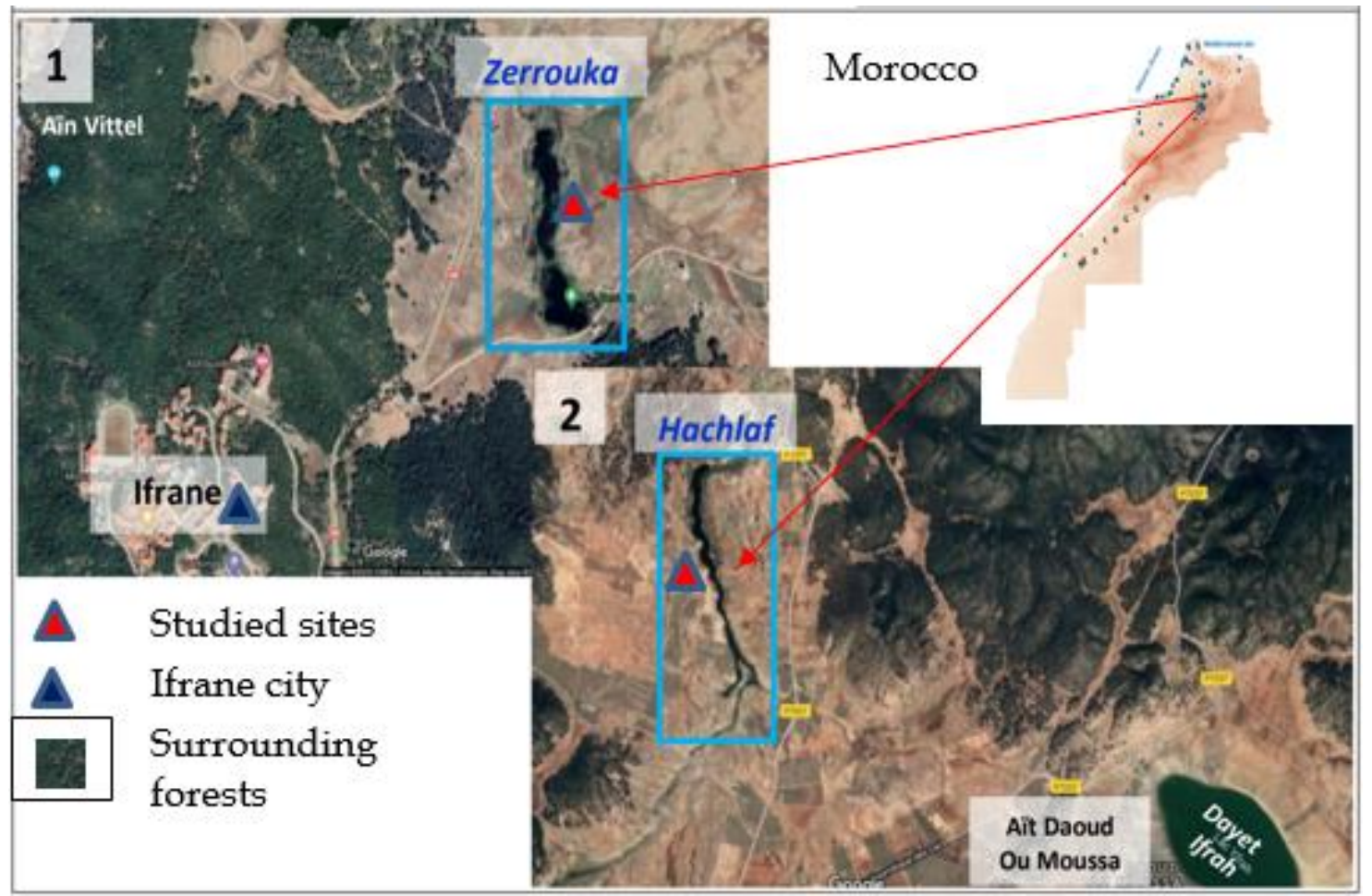

Figure 1 Localization of studied sites Zerrouka and Hachlaf Lakes. 


\subsection{Statistics}

Statistical analyses were done in STATGRAPHICS Centurion software (version XVI.I). Before running these analyses, we checked for normality and homogeneity of variance for all variables with the Kolmogorov-Smirnov test. Spearman Rank Correlation was used to test the relationship among nest dimensions in crested coot. Besides, to assess differences in nesting dates (first nests of each season), laying dates (first eggs of each season), and hatching dates (first hatched eggs) between Zerrouka and Hachlef, we used the independent $t$-test, and considering the two sites as unrelated ecosystems. Results were given as sample size and mean $\pm S D$, and graphs were created by GraphPad Prism Mac $6.0 \mathrm{~h}$ software.

\section{Results}

\subsection{Nesting behavior and egg dimensions}

The crested coot (Fulica cristata) nesting behavior differed between the studied sites. At Zerrouka artificial reservoir, nests were built in open waters and boundaries, using plant materials surrounding the nesting habitat. The Typha, bulrush, and poplar twigs were the main plant species identified in nests. On the contrary, at Hachlaf Lake, nests were built in islets of submerged vegetation far from lake borders. Nests were constructed mainly with poplar twigs and leaves and other minor twigs, including Polygonum sp., Ceratophylls sp. and Milfoils sp. fragments.

In terms of nest features, crested coot built different nests in studied lakes. Nest dimensions, including big diameter and small diameter, were larger in Zerrouka Lake (Table 1), with a significant correlation between all parameters (Table 2). On the other hand, crested coot built its nests on a height upon water stream to avoid high water levels that could submerge nests and cause breeding failure.

\subsection{Breeding chronology}

Breeding phenology varied between studied sites, including nesting, laying, and hatching dates (Figure 2). At Hachlaf Lake, nesting behavior and crested coot activities started during the third week of April and continued until the second week of June. Also, the laying activity was between April and June. On the other side, in Zerrouka, nesting activities started earlier $(\mathrm{n}=8, \mathrm{t}=2.09756, P$-value $=0.054)$ during the fourth week of February, while the last nest was recorded last week of June (Figure 3). In parallel, laying activity started from the third week of March and continued until May end. While hatching was observed from the third week of April until the second week of June, with a maximum occurrence during the fourth week of April. Furthermore, hatching occurred between the last week of February until the end of May, with maximum hatching during the second week of April.

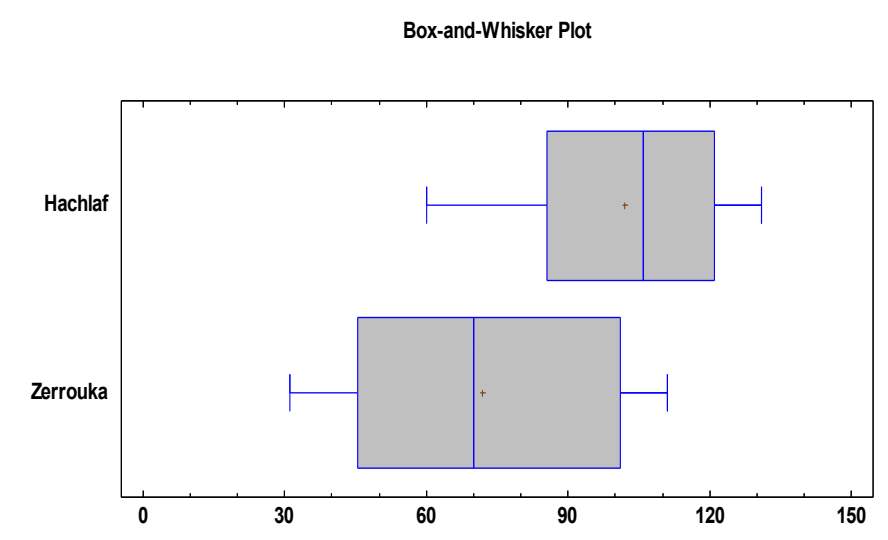

Figure 2 Two-sample Comparison of breeding chronology in crested coot at Zerrouka and Hachlaf lakes between 2018-1019.

Table 1 Characteristics of crested coot nests (dimension and placement) at studied sites.

\begin{tabular}{ccccc}
\hline Parameters & Average & SE & Minimum & Maximum \\
\hline Outer diameter of the nest $(\mathrm{cm})$ & 36.30 & 2.12 & 33 & 41 \\
Inner diameter of the nest $(\mathrm{cm})$ & 19.31 & 2.59 & 16 & 24 \\
Nest height $(\mathrm{cm})$ & 13.01 & 2.4 & 10 & 18 \\
Lake depth under the nest $(\mathrm{cm})$ & 77.6 & 23.1 & 52 & 120 \\
\hline
\end{tabular}

Table 2 Spearman Rank Correlations among nest dimensions (54 nests) in crested coot.

\begin{tabular}{ccccc}
\hline & $\begin{array}{c}\text { Big diameter } \\
(\mathrm{cm})\end{array}$ & $\begin{array}{c}\text { Small diameter } \\
(\mathrm{cm})\end{array}$ & $\begin{array}{c}\text { Height upon } \\
\text { water level }\end{array}$ & $\begin{array}{c}\text { Nest depth } \\
(\mathrm{cm})\end{array}$ \\
\hline Big diameter $(\mathrm{cm})$ & - & 0.9189 & 0.5018 & 0.7793 \\
$P$-Value & - & 0.0002 & 0.0385 & 0.0013 \\
Small diameter $(\mathrm{cm})$ & 0.9189 & - & 0.3146 & 0.6153 \\
$P$-Value & 0.0002 & - & 0.1946 & 0.0112 \\
Height upon water level & 0.5018 & 0.3146 & - & 0.4239 \\
$P$-Value & 0.0385 & 0.1946 & - & 0.0805 \\
Nest depth $(\mathrm{cm})$ & 0.7793 & 0.6153 & 0.4239 & - \\
$P$-Value & 0.0013 & 0.0112 & 0.0805 & - \\
\hline
\end{tabular}




\section{Discussion}

Nesting behavior and breeding chronology in bird species are widespread, commonly observed activities. Yet, we understand relatively little information about how these species construct what seem to be species-specific nests (Walsh et al 2010) and nestling success. Similarly, despite being a widespread species, little is known about the nesting and breeding features of the Crested coot, mainly in high altitude zones. However, throughout this field research, we have investigated nesting behavior's main features, including nesting-sites, morphology, materials, and the breeding chronology of crested coot at high altitude habitats.

The analysis of 54 nests indicated that crested coot built big sized-nests to support its clutches and nestling in Zerrouka and Hachlaf lakes. These findings are similar to the results mentioned in $\mathrm{f}$ the Eurasian coot Fulica atra in the Fez region, $70 \mathrm{~km}$ to our study sites (Squalli et al 2020). Besides, (Collias and Collias 1984; Hansell 2000) have reported a close correlation between species body and nest morphology, and suggesting a species-nest relation. In our case, the Eurasian coot and crested coot are body-size similar species, which support the similarity in nest dimensions. On the other hand, the construction of nests in the high platform upon water level and open waters at Zerrouka and islets on submerged vegetation at Hachlaf is supposed to be adaptive predators, and human disturbance are existing in borders of lake waters. Similar results were reported in the Eurasian coot, which built nests in high-density vegetation habitats to escape predators (Squalli et al., 2020). This strategy is widely reported in bird species (Frederick and Collopy 1989; Schüttler et al 2009), including the Eurasian coot (Del Hoyo et al 1996; Taylor and Van Perlo, 1998) as adaptive behavior to face the predation risk, especially during the incubation where the adults and nestling are in the nests (Brzeziński et al 2018; Engel et al 2020). In parallel, crested coot uses the available vegetation twigs, including Typha and poplars, to build its nests.

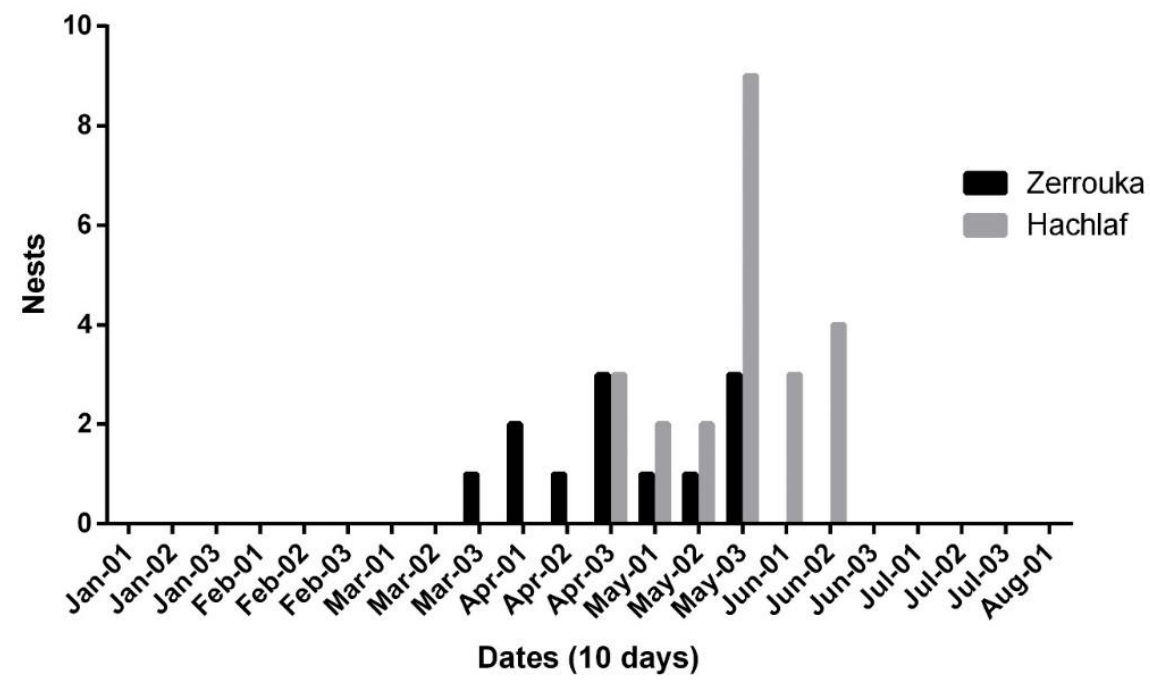

2019

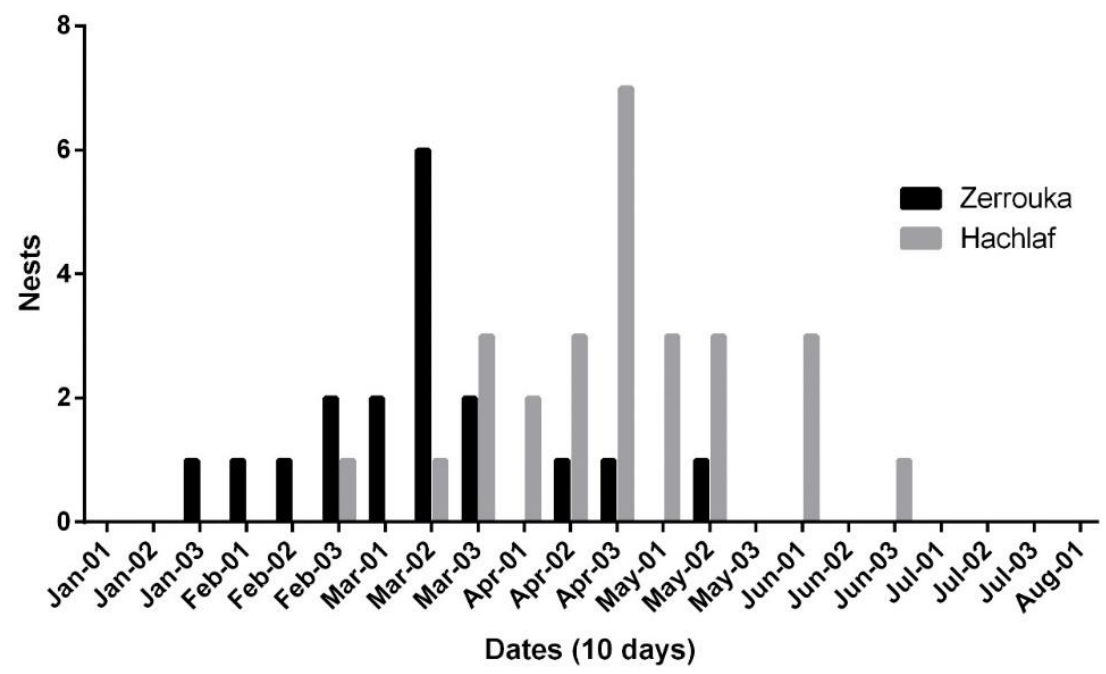

Figure 3 Nesting chronology of the crested coot in Zerrouka and Hachlaf lakes during two breeding seasons (2018 and 2019 ). 
Breeding activities started earlier at Zerrouka by nesting during the last week of February, while at Hachlaf, nesting activities started during April. Similarly, the laying phase started first at Zerrouka compared to Hachlaf. This result is in agreement with those reported in the South of Spain (Varo 2008). Generally, crested coot starts its breeding season between February and August in the Mediterranean basin, with variability from one habitat to another (Taylor and Van Perlo 1998), which explicit the difference between Zerrouka and Hachlaf lakes. Compared with the Eurasian coot in the same region, (Squalli et al 2020; Zitouni 2014) have reported a breeding season in Fulica atra between March and July, close to our results. Generally, breeding season in the majority of bird species is an adaptive strategy to environmental conditions (Smith et al 2010), food abundance (Mansouri et al 2019; Stone et al 2017), and habitat quality (Hollander et al 2012). Therefore, the variation of these factors from habitat to another controls the breeding season's initiation in the crested coot and other avian species.

\section{Conclusions}

In conclusion, this study provides an initiation to identify breeding sites, nesting strategies, and breeding chronology of the crested coot Fulica cristata in North African wetlands. The crested coot nestled in the Hachlaf and Zerrouka Lakes between February and June. Moreover, this water bird uses the available plant twigs as nesting materials, and nests are built on open water and submerged vegetation to avoid predators and water levels. Similarly, nest dimensions were variable from one habitat to another.

\section{Conflict of Interest}

The authors declare that there are no conflict of interest with this work.

\section{Funding}

This research did not receive any financial support.

\section{References}

Amat Juan A, Green AJ (2010) Waterbirds as bioindicators of environmental conditions. Conservation monitoring in freshwater habitats 45-52.

Amat Juan A, Raya C (2004) Focha moruna Fulica cristata. Libro rojo 199.

Amezian M, Louah A, Thompson I, Cortes J, El Hassouni M, Qninba A (2007) Les récents changements dans la composition du peuplement d'oiseaux d'eau nicheurs des marais de Smir (Nord-Ouest du Maroc) $35 \mathrm{pp}$

Balbontín J, Møller AP, Hermosell IG, Marzal A, Reviriego M, De Lope F (2009) Divergent patterns of impact of environmental conditions on life history traits in two populations of a long-distance migratory bird. Oecologia 159:859-872. https://doi.org/10.1007/s00442-008-1267-8

Both C, Te Marvelde L (2007) Climate change and timing of avian breeding and migration throughout Europe. Climate Research 35:93-105. https://doi.org/10.3354/cr00716

Brzeziński M, Chibowski P, Gornia J, Górecki G, Zalewski A (2018) Spatiotemporal variation in nesting success of colonial waterbirds under the impact of a non-native invasive predator. Oecologia.

Collias N, Collias EC (1984) Nest building and bird behavior. Princeton, NJ: Princeton University Press.
Del Hoyo J, Elliott A, Sargatal J (1996) Handbook of the Birds of the World, Hoatzin to Auks. Lynx Edicions, Barcelona, Spain.

El Agbani MA, Qninba A, Radi M, El Hamoumi R, Cherkaoui SI, Himmi O, Dakki $M$ (2011) Les oiseaux d'intérêt patrimonial au Maroc, Publications du GREPOM, Rabat, 3:29 pp.

El Hassouni M, Qninba A, Amezian M, Cuzin F, Dakki M (2009) Le peuplement d'oiseaux d'eau du complexe des zones humides de Smir (Nord du Maroc): État actuel, intérêt patrimonial et évolution depuis les quatre dernières décennies. Bull. Inst. Sci., Rabat, Section Sciences de La Vie 31:103-110.

Engel N, Végvári Z, Rice R, Kubelka V, Székely T (2020) Incubating parents serve as visual cues to predators in Kentish plover (Charadrius alexandrinus). PLoS ONE 15:e0236489. https://doi.org/10.1371/journal.pone.0236489

Frederick PC, Collopy MW (1989) The Role of Predation in Determining Reproductive Success of Colonially Nesting Wading Birds in the Florida Everglades. The Condor 91:860-867. https://doi.org/10.2307/1368070

Hammada S, Dakki M, Ibn Tattou M, Ouyahya A, Fennane M (2002) Catalogue de la flore des zones humides du Maroc. Bull. Inst. Sci., Rabat, 60 p.

Hansell M (2000) Bird Nests and Construction Behaviour. Cambridge University Press.

Hilton GM, Hansell MH, Ruxton GD, Reid JM, Monaghan P (2004) Using Artificial Nests to Test Importance of Nesting Material and Nest Shelter for Incubation Energetics. The Auk 121:777-787. https://doi.org/10.1642/00048038(2004)121

Hollander F, Titeux N, Van Dyck H (2012) Territorial resource valuation deviates from habitat quality in an ecologically trapped, long-distance migratory bird. Behavioral Ecology and Sociobiology 66:777-783. https://doi.org/10.1007/s00265-012-1325-4

Madrono A, Gonzalez C, Atienza J (2004) Libro Rojo de las aves de Espana. SEP/BirdLife, Madrid.

Mansouri I, Al-Sadoon MK, Rochdi M, Paray BA, Dakki M, Elghadraoui L (2019) Diversity of feeding habitats and diet composition in the turtle doves Streptopelia turtur to buffer loss and modification of natural habitats during breeding season. Saudi Journal of Biological Sciences 26:957-962.

Mansouri I, Mounir M, Squalli W, Elhanafi L, Dakki M, El Ghadraoui L (2020) Migratory Dates, Breeding Phenology, and Reproductive Success of European Turtle Doves between Lowlands and Highest Breeding Habitats in North Africa. International Journal of Zoology 7pp.

Martin TE (1987) Food as a limit on breeding birds: A life-history perspective. Annual Review of Ecology and Systematics 18:453-487.

Moller AP (2006) Rapid change in nest size of a bird related to change in a secondary sexual character. Behavioral Ecology 17:108-116.

Møller AP, Fiedler W, Berthold P (2010) Effects of climate change on birds. OUP Oxford.

Newton I (1979) Population Ecology of Raptors. Vermillion, South Dakota: Buteo Books.

Raby CR, Clayton NS (2009) Prospective cognition in animals. Behavioural Processes 80:314-324. https://doi.org/10.1016/j.beproc.2008.12.005

Schüttler E, Klenke R, McGehee S, Rozzi R, Jax K (2009) Vulnerability of ground-nesting waterbirds to predation by invasive American mink in the Cape Horn Biosphere Reserve, Chile. Biological Conservation 142:1450-1460.

Smith PA, Gilchrist HG, Forbes MR, Martin JL, Allard K (2010) Inter-annual variation in the breeding chronology of arctic shorebirds: Effects of weather, snow melt and predators. Journal of Avian Biology 41:292-304. https://doi.org/10.1111/j.1600-048X.2009.04815.x

Squalli W, Mansouri I, Dakki M, Fadil F (2020) Nesting habitat and breeding success of Fulica atra in tree wetlands in Fez's region, central Morocco. Journal of Animal Behaviour and Biometeorology 8:282-287. https://doi.org/10.31893/jabb.20037

Stone D, Cherry M, Martin J, Cohen B, Miller K (2017) Breeding chronology and social interactions affect ungulate foraging behavior at a concentrated food resource. PLOS ONE 12:e0178477. 
Taylor B, Van Perlo B (1998) Rails: A guide to the Rails, Crakes, Gallinules and Coots of the World. Pica Press, Sussex.

Varo N (2008) Breeding biology of two sympatric coots with contrasting conservation status. Bird Study 55:314-320.

Walsh PT, Hansell M, Borello WD, Healy SD (2010) Repeatability of nest morphology in African weaver birds. Biology Letters 6:149-151.
Wimberger P (1984) The use of green plant material in bird nests to avoid ectoparasites. The Auk101:615-618.

Zitouni A (2014) Ecologie de la reproduction de la Foulque macroule (Fulica atra) dans le Lac Tonga (Parc National d'El-Kala). Thèse de Doctorat en Biologie animale, Université Badji Mokhtar, Annaba. 